\title{
ERRATUM
}

\section{Review of Les prix Nobel: Sociologie d'une élite transnationale, by Josepha Laroche- ERRATUM}

\author{
Moussaoui, F.
}

doi:10.1017/S0008423913000814, Published by Cambridge University Press, 6 January 2014.

In the original publication of the review of Les prix Nobel: Sociologie d'une élite transnationale, by Josepha Laroche, the author of the review was incorrectly listed. The correct author of the book review is Étienne Girouard, not Farid Moussaoui. The error has been corrected in the online HTML and PDF copies. We apologize for this error.

\section{Reference}

Girouard, É. (2014) Review of "Les prix Nobel: Sociologie d'une élite transnationale," by Josepha Laroche. Canadian Journal of Political Science/Revue canadienne de science politique, 46:3, 739-740. doi:10.1017/S0008423913000814. 